\title{
Impact of Displacement on Civil and Political Rights of the Internally Displaced Persons in Dolakha District of Nepal
}

\author{
Netra Bahadur Karki \\ Deputy Superintendent of APF, Nepal \\ Course Coordinator and Directing Staff \\ APF Commend and Staff College, Kathmandu, Nepal \\ Email: netrakrk@yahoo.com
}

\begin{abstract}
The explanatory paper discusses the impact of displacement on the civil and political rights of the internally displaced persons (IDPs) in Dolakha District of Nepal with special reference to the displacement caused by the 2015 Nepal Earthquake. The discussion has focused on studying the answer for whether the disaster-induced IDPs enjoyed the civil and political rights particularly during the Federal, Provincial and Local elections in Nepal. The findings are based on the primary data collected from the respondents, IDPs and the people's representatives, who are the key aspect of the real time empirical familiarity, and of course supported by secondary data. The main issue in the paper is whether the IDPs could enjoy the civil and political rights during the tri-phases of election in 2017 in Dolakha District of Nepal, and the claim is that some of the civil and political rights of the IDPs were unconstructively impacted because of their status of being displaced.
\end{abstract}

Key Words: Civil and political rights, disaster, election, internal displacement, IDPs

\section{Introduction}

Internal armed conflict 1996-2006 remained the significant contributor to let the public know about internally displaced persons (IDPs) in Nepal, even though disaster has been prominent contributor. Nepal was defectively struck by the earthquake in April 2015 killing nearly nine thousand and leaving thousands homeless to become IDPs (International Organization for Migration, 2015). Disasters, especially earthquake and flooding, have been other terrible causes of internal displacement. Nepal Earthquake 2015 alone displaced above 2.6 million people in Nepal ("Nepal third in internal displacement by natural disasters," 2016). The displacements Nepal faces vary depending mainly upon occurrence of indents of natural disasters specially earthquake and flooding. Nepal did not face any earthquake shaking in the year 2017 but the number of IDPs was remarkable. The number of disasterinduced IDPs in Nepal was 384,000 in the year 2017 (IDMC, 2018).

Dolakha, a mountainous District, lies in Province No. 3 in the northern part of Nepal. The district is 133 kilometers far from the capital city Kathmandu and 141 kilometers from Janakpur, the nearest big city in Tarai. Dolakha, laid on the lap of Mount Gaurishankar, is worth mentioning district from touristic point of view due to the historical, religious, cultural and natural beauty (District Development Committee, Dolakha, 2015). Maximum land of the district is covered by high hills and mountains, and only ten percent of the land is flat (DDC, Dolakha, 2015). Seventy percent of the land in Dolakha is more than 30 degree slope. Around 92 percent of the population in the district depends on agriculture (DDC, Dolakha, 2015). Together with other districts, Dolakha was also badly hit by the Nepal Earthquake 2015. The report of DDC, Dolakha (2015) states that the number of people injured was 663 and death toll was 177. Total number of the people's houses destroyed was 58,388 which include 55,873 fully destroyed and 1,506 partially destroyed. These numbers of the destroyed houses include only the private ones. For describing current status, some of the IDPs have still complained in the local bodies of missing from the list of beneficiary, but most of them have already received second round of reconstruction payment from National Reconstruction Authority. The number of reconstruction beneficiary is 51,940 and retrofitting beneficiary is 637 from Dolakha ("Map of beneficiaries in Dolakha," 2018).

Nearly 90 percent of the houses were fully destroyed by the earthquake in Dolakha (DDC, Dolakha, 2015). The effected families were uprooted from their residents to become IDPs. The life condition of those displaced had been observed feeble in the pitiful shelters. The displaced were often in need of ensuring their access to basic requirements at least for their survival including basic services such as food, water, health and education. During this situation, Nepal has moved through the three tiers of election for federal, provincial and local governments but the question "have the IDPs enjoyed their civil and political rights?" remains unexplored. In this backdrop, the paper endeavors to discuss the issues: 
effects of displacement on IDPs, impact of displacement on the civil and political rights of the IDPs and the causes of those effects in Dolakha District of Nepal.

\section{Defining Internally Displaced Person}

IDPs are the people uprooted from their habitual residence but have not crossed the state border. These people are forced to flee their homes due to the situations like armed conflict, situations of generalized violence, violations of human rights, natural or human-made disasters ("Guiding principles on internal displacement," 1998; "National policies on internally displaced persons," 2007). The "Guiding principles on internal displacement" (1998) did officially define IDPs as

persons or groups of persons who have been forced or obliged to flee or to leave their homes or places of habitual residence, in particular as a result of or in order to avoid the effects of armed conflict, situations of generalized violence, violations of human rights or natural or human-made disasters, and who have not crossed an internationally recognized state border (p. 1).

This definition by United Nations Guiding Principles is widely used one which paved the way for further minutely perceiving the causes and effects of the internal displacements. Slightly more elaborative definition comes from the "National policies on internally displaced persons" (2007), according which IDP is

a person who is living somewhere else in the country after having forced to flee or leave one's home or place of habitual residence due to armed conflict or situation of violence or gross violation of human rights or natural disaster or humanmade disaster and situation or with an intention of avoiding the effects of such situations (p. 3).

Following the Guiding Principles, international community realized the need of addressing the internal displacement issues. African Union was the first regional organization to adopt convention on internal displacement. This "Kampala Convention," (2009) adds development projects and harmful practices as the causes of displacement. Refinement on the definition of internal displacement continued and "National policy on internally displaced persons (IDPs) in Nigeria" (2012) included extreme poverty, lack of equal access to socio-economic resources, imbalanced development, unemployment, environmental-induced displacements in the list of causes. In this paper, internal displaced caused by the earthquake is considered in discussion for the study purpose.

\section{Standpoint on Civil and Political Rights}

The civil rights ensure the liberty and freedom of the people. Civil rights include the right to life, dignity, protection, equality, non-discrimination, movement, expression, assembly, privacy. The political rights guarantee the participation of the people in the government. Political rights include right to fair trail, association, petition, elect and to be elected. The civil and political rights protect the freedom of the people against encroachment by the state, social organizations and private individuals ("Civil and political rights," 2001). From the normative integrated perspective on rights, civil and political rights incorporates other rights such as economic, social and cultural (Elisabeth Koch, 2006).

The International Covenant on Civil and Political rights (ICCPR), 1966 protects the civil and political rights of the citizens in their respective states ("ICCPR," 1966; Joseph \& Castan, 2013). The Constitution of Nepal, 2015 has a more comprehensive list of fundamental rights relating to the civil and political rights of the citizens, which includes wider range of rights that are not incorporated in the ICCPR. The "Constitution of Nepal" (2015) and the "ICCPR" (1966) have conferred the civil and political rights as shown in the following table 1 . In this study, the basis of discussion on the civil and political rights is primarily based on the international instrument that is ICCPR.

Table 1: Civil and Political Rights as Conferred in the Constitution of Nepal, 2015 and ICCPR, 1966

\begin{tabular}{|l|l|l|}
\hline \multicolumn{1}{|c|}{ Attributes of Civil and Political Rights } & $\begin{array}{c}\text { Conferred in the } \\
\text { Constitution of } \\
\text { Nepal, 2015 }\end{array}$ & \multicolumn{1}{|c|}{$\begin{array}{c}\text { Conferred in the } \\
\text { ICCPR, 1966 }\end{array}$} \\
\hline Right to life and live with dignity & Article 16 & Articles 6, 10 \\
\hline Freedom of opinion and expression & Article 17 & Article 19 \\
\hline Freedom to assemble peaceably & Article 17 & Articles 21, 25 \\
\hline Freedom to form political parties & Article 17 & Articles 22, 25 \\
\hline
\end{tabular}


34 | Journal of APF Command and Staff College

\begin{tabular}{|l|l|l|}
\hline Freedom to form unions and associations & Article 17 & Articles 22, 25 \\
\hline Freedom of movement & Article 17 & Article 11 \\
\hline Equal protection of law & Article 18 & Articles 3, 9, 14, 26 \\
\hline Right to communication & Article 19 & - \\
\hline Rights relating to justice & Article 20 & Articles 9, 14 \\
\hline Right of victim of crime & Article 21 & - \\
\hline Right against torture & Article 22 & Articles 7, 8 \\
\hline Right against preventive detention & Article 23 & Article 9 \\
\hline Right against untouchability and discrimination & Article 24 & Article 20 \\
\hline Right relating to property & Article 25 & Article 17 \\
\hline Right to freedom of religion & Article 26 & Article 18 \\
\hline Right to information & Article 27 & Article 19 \\
\hline Right to privacy & Article 28 & Article 17 \\
\hline Right against exploitation & Article 29 & Article 8 \\
\hline Right to clean environment & Article 30 & - \\
\hline Right relating to education & Article 31 & Article 24 \\
\hline Right to language and culture & Article 32 & Article 27 \\
\hline Right to employment & Article 33 & - \\
\hline Right to labour & Article 34 & Article 8 \\
\hline Right relating to health & Article 35 & Article 18 \\
\hline Right relating to food & Article 36 & - \\
\hline Right to housing & Article 37 & - \\
\hline Rights of women & Article 38 & Articles 3, 6, 23 \\
\hline Rights of the child & Article 39 & Articles 10, 24 \\
\hline Rights of senior citizens & Article 41 & - \\
\hline Right to social justice & Article 42 & Article 27 \\
\hline Right to social security & Article 43 & Article 27 \\
\hline Rights of the consumer & Article 44 & - \\
\hline Right against exile & Article 45 & - \\
\hline Right to family & - & Article 23 \\
\hline
\end{tabular}

Source: The "Constitution of Nepal" (2015) and the "ICCPR" (1966)

\section{Review of Literature}

The displaced persons are noticeably obliged to face hard moments due to fleeing from homegrown places in the search of sanctuary. There are generation of various and uncommon portions of life as well as some kind of emotion of insecurity to the IDPs and noticeable additional security challenges to the host community and the state authority as well. As per Cohen (2004), internal displacement has become one of the most stressing security concerns today. The shortage or scarce of the daily basic needs creates chaos in the location. Cohen (2004) argued that internal displacement poses threat to national solidity. IDPs face local unfriendliness while returning as well (Fagen, 2004). According to Lischer (2008), the displacement pessimistically affects the law and order of the society. Swain (2006) claimed that there is existence of conflicts between locals and migrants because of the lessened values and cultural maladjustments. The disinclination of resource sharing can be the reason of the hostile behaviour of the host community. García Amado (2016) sees residential security of the IDPs and host/return community as the immense concern.

Bearing the responsibility of managing internal displacement has been of less priority for most of the states (Cohen, 2004). States are mainly responsible for managing internal displacement but resource limitation may pose constrain. Sri Lankan effort on dealing with the IDPs during counter insurgency was fine. India's response to Kashmiri displacement is better but at the same time trifling in northeast (Cohen, 2004). The host society hardly welcome IDPs' persistent stay but government's effort to support can be extensively supported by the civil society when rationally called for (Rekhviashvili, 2015).

Mertus (2004) stated that displacement leads to theatrical changes in family construction and gender roles. The changing roles make vulnerable people like women and elders go out for their livelihood. Perpetrators can exploit this situation of helplessness. Mertus (2004) further elaborated that IDPs' life is influenced by the cultural values of the surrounding communities. The displaced persons are forced to 
adapt in new location for long or time being. There is no choice to adopt the strange locality for the displaced persons. Eweka and Olusegun (2016) claims that the improper management of the IDPs may make the countries prone to violent conflicts (p. 207). States may not have capability to address the eventualities of displacement and they may call for national-international support. The tension of IDP's could be eased by the willingness of government that can provide a huge relief to the IDPs. Eweka and Olusegun (2016) opine that the only the way to manage the internal displacement is through working together by the stakeholders.

Most of the literatures indicate that there exist problems when displacements occur, but without linking them with the civil and political rights of the IDPs. This pertinent issue regarding IDPs has not been the subject of investigation in Nepal. At this point, this study has aimed to explain the displacement in Dolakha district and its impact on the civil and political rights of the IDPs.

\section{Methodology of the Study}

The study will be based on the displacement caused by the Nepal Earthquake 2015 with particular reference to the impact made on the civil and political rights of the IDPs. Civil and political rights are the concerns of the study mainly taking the local, and provincial and federal elections respectively held on 14 May and 26 November 2017 in Dolakha District of Nepal into consideration. Dolakha District was chosen for the study because of some specific incidents like killing of the person during the election ("Man dies in Dolakha police firing," 2017).

There were some villages in danger in the district which need to be transferred to the safe locations. The number of the effected persons in those villages was above hundred in five local bodies namely Bhimeshwor municipality, and Kalinchok, Baiteshwor, Shailungeshwor and Melung rural municipalities. Among these five, three local bodies namely Baiteshwor, Bhimeshwor and Kalinchok were selected for the questionnaire with IDPs through network sampling method, where the security officials posted in Company Headquarters of Armed Police Force, Nepal in Dolakha and permanently residing in those local bodies were used for the networking. Ten IDPs from each local body were sampled for the structured questionnaire through simple random sampling, as first ten were sampled via lottery from the list of the available persons in the village on the day of data collection. There are nine local bodies in Dolakha. Among eighteen Heads/Deputy Heads of the local bodies, six (three Heads and three Deputy Heads) were selected as the sample through systematic random sampling. Out of seventy-four Chairpersons of the Wards, nine were sampled through systematic random sampling. Among those respondents of the questionnaire, nine IDPs were again selected through the simple random sampling for the telephone interview. There was semi-structured telephone interview with these IDPs, Heads/Deputy Heads and Ward chairpersons. The explanatory telephone interview was aimed at finding out the causes of being able/unable to enjoy the civil and political rights by the IDPs. The interview was targeted to probe the causes of changed impact on the rights after being displaced due to the Nepal Earthquake 2015 based on empiricism. The data received from the questionnaire gave an idea to conduct telephone interview.

\section{Findings and Result Discussion}

\section{Effects of Displacement on IDPs in Dolakha}

The Nepal Earthquake 2015 caused huge loss of life and property, and left deepening unpleasant impact on the life style of the people (DDC, Dolakha, 2015). The effects of displacement on IDPs' life are assorted and vary from place to place depending upon the situation. Some affected places were easily accessible for relief distribution and some were not. To find out the common effects of the displacement on displaced persons, questionnaire was carried out that found the effects as shown in the table 2 .

Table 2: Effects of Displacement on IDPs' Life

\begin{tabular}{|l|l|c|c|}
\hline \multirow{2}{*}{ S.N. } & \multirow{2}{*}{ Effects of Displacement } & \multicolumn{2}{|c|}{ Responses (in percentages) from IDPs (N=30) } \\
\cline { 3 - 4 } & & Yes & No \\
\hline 1. & Death of Relatives & 13.3 & 86.7 \\
\hline 2. & Self Injury & 36.7 & 63.3 \\
\hline 3. & Injury to Relatives & 43.3 & 56.7 \\
\hline 4. & Emotional and Mental Trauma & 53.3 & 46.7 \\
\hline 5. & Lack of Food & 93.3 & 6.7 \\
\hline
\end{tabular}


36 | Journal of APF Command and Staff College

\begin{tabular}{|l|l|c|c|}
\hline 6. & Lack of Clothes & 96.7 & 3.3 \\
\hline 7. & Financial Problem & 100.0 & 0.0 \\
\hline 8. & Homeless & 93.3 & 6.7 \\
\hline 9. & Loss of Agro Field & 100.0 & 0.0 \\
\hline 10. & Loss of Animals and Birds & 86.7 & 13.3 \\
\hline 11. & Landlessness & 50.0 & 50.0 \\
\hline 12. & Bad effect on Education & 73.3 & 26.7 \\
\hline 13. & Lack of Health Facilities & 66.7 & 33.3 \\
\hline 14. & Lack of Water & 56.7 & 43.3 \\
\hline 15. & Lack of Electricity & 46.7 & 53.3 \\
\hline 16. & Lack of Firewood & 43.3 & 56.7 \\
\hline
\end{tabular}

First ten effects in the list of the table 2 were included in the structured questionnaire but remaining six came through the option 'other effects'. Death and injury were the earliest effects of the displacement. Some 40 percent of the respondents also received some types of injury during the earthquake. In such displacements, IDPs largely feel the paucity of the health services (Adekola, Allen, \& Tinuola, 2017). Around 60 percent of the respondents stated that they lacked health services. Remarkable 53.5 percent said that they went through some kind of emotional/mental trauma.

Education is another considerable area negatively impacted due to the displacement (Ambe-Uva, 2012). Above 70 percent respondents agreed upon the unconstructive effect on the education due to the displacement. The Earthquake 2015 caused remarkable loss of economic production (Salgado-Gálvez, 2018). Hundred percent of the respondents stated that they faced financial problems and also lost agricultural products during earthquake. Around 90 percent of the respondents were homeless, lost their animals and birds, and experienced the lack of food and clothes. Some half of the respondents also faced the problems of water, electricity, firewood, and land to reconstruct house because government of Nepal declared some of the locations danger place to live.

The effects of displacement as enlisted in the table 2 are in fact those rights enlisted in table 1 in slightly different forms. Lack of health facilities is the deprivation of the right relating to food that the Constitution of Nepal protects. Without ensuring public health, rights can never be guaranteed (Toebes, 2015). Dolakha as a hilly district is geographically harsh to reach but the basic requirements are similar for all locations. All the stakeholders working hand in hand is the only instrument to ensure citizens' access to health care services (Orach et al., 2009). Similarly, homelessness is the deficiency on the right to housing. The imagination of the welfare state is almost impossible without ensuring the right to housing (Casla, 2016; Yung \& Lee, 2012). Government mechanism needs to be sensitive in guaranteeing the right to education (Banks \& Carbonell, 2013). We can observe that there is more or less deficiency on the right relating to property, employment, social justice, education basic needs and of course right to live with dignity, which are conferred in both the Constitution and the ICCPR.

\section{Displacement and Its Impact on Civil and Political Rights of the IDPs in Dolakha}

The political rights guarantee the liberty to contribute to the process of governing the society and the county as a whole. The displaced people as the citizen of the state have equal right to freedom of movement so that freedom of participation in religious, cultural, economic, social and political activities can be ensured. These rights should not be alienated for being an IDP. The state has the responsibility to respect, protect and fulfill the rights. In fact, civil and political rights including economic and social rights of the citizen are of primary concern for any good governments (Yigen, 2000). The table 3 shows the responses of structured questionnaire from IDPs and semi-structured telephone interview with the IDPs, and heads/deputy heads and ward chairpersons of the local bodies.

Table 3: Effects of Displacement on Civil and Political Rights

\begin{tabular}{|c|c|c|c|c|c|c|c|}
\hline \multirow[t]{3}{*}{ S.N. } & \multirow[t]{3}{*}{$\begin{array}{c}\text { Considerations within Civil } \\
\text { and Political Rights }\end{array}$} & \multicolumn{2}{|c|}{$\begin{array}{l}\text { Responses (in percentages) from } \\
\text { IDPs through Questionnaire } \\
(\mathbf{N}=\mathbf{3 0})\end{array}$} & \multicolumn{4}{|c|}{$\begin{array}{l}\text { Responses (in percentages) from } \\
\text { Heads/Deputy Heads of Local } \\
\text { Bodies, Ward Chairpersons and } \\
\text { IDPs }(6+9+9) \text { through Telephone } \\
\text { Interview }(\mathrm{N}=24)\end{array}$} \\
\hline & & $\begin{array}{c}\text { Before } \\
\text { Displacement }\end{array}$ & $\begin{array}{c}\text { After } \\
\text { Displacement }\end{array}$ & $\begin{array}{r}\text { B } \\
\text { Disp }\end{array}$ & nent & Disp & nent \\
\hline & & Yes & Yes & Yes & No & Yes & No \\
\hline
\end{tabular}


Karki: Impact of Displacement on Civil and Political...| 37

\begin{tabular}{|l|l|c|c|c|c|c|c|c|c|}
\hline 1. & Personal and Family Security & 90.0 & 10.0 & 91.6 & 8.4 & 75.0 & 25.0 & 91.6 & 8.4 \\
\hline 2. & Community Security & 93.3 & 6.7 & 93.3 & 6.7 & 75.0 & 25.0 & 83.3 & 16.7 \\
\hline 3. & Freedom of Movement & 76.7 & 23.3 & 80.0 & 20.0 & 62.5 & 37.5 & 91.6 & 8.4 \\
\hline 4. & Human Dignity and Respect & 96.7 & 3.3 & 73.3 & 26.7 & 83.3 & 16.7 & 75.0 & 25.0 \\
\hline 5. & $\begin{array}{l}\text { Respect and Security of } \\
\text { Children and Elderly People }\end{array}$ & 50.0 & 50.0 & 30.0 & 70.0 & 83.3 & 16.7 & 62.5 & 37.5 \\
\hline 6. & $\begin{array}{l}\text { Exploitation and Violation } \\
\text { against Women }\end{array}$ & 16.7 & 83.3 & 30.0 & 70.0 & 62.5 & 37.5 & 41.6 & 58.4 \\
\hline 7. & $\begin{array}{l}\text { Fair Listening and Addressing } \\
\text { the Problems by Government } \\
\text { Authority }\end{array}$ & 40.0 & 60.0 & 53.3 & 46.7 & 25.0 & 75.0 & 83.3 & 16.7 \\
\hline 8. & Freedom of Association & 50.0 & 50.0 & 73.3 & 26.7 & 50.0 & 50.0 & 83.3 & 16.7 \\
\hline 9. & $\begin{array}{l}\text { Freedom of Joining Interested } \\
\text { Political Party }\end{array}$ & 66.7 & 33.3 & 93.3 & 6.7 & 50.0 & 50.0 & 79.1 & 20.9 \\
\hline 10. & $\begin{array}{l}\text { Freedom of Participating in } \\
\text { Political Activities }\end{array}$ & 60.0 & 40.0 & 46.7 & 53.3 & 25.0 & 75.0 & 83.3 & 16.7 \\
\hline 11. & Freedom of Expression & 73.3 & 26.7 & 90.0 & 10.0 & 50.0 & 50.0 & 91.6 & 8.4 \\
\hline 12. & Freedom of Political Campaign & 76.7 & 23.3 & 30.0 & 70.0 & 62.5 & 37.5 & 79.1 & 20.9 \\
\hline 13. & Luring Voters & 46.7 & 53.3 & 70.0 & 30.0 & 62.5 & 37.5 & 62.5 & 37.5 \\
\hline 14. & $\begin{array}{l}\text { Security of Movement for } \\
\text { Election }\end{array}$ & 50.0 & 50.0 & 60.0 & 40.0 & 25.0 & 75.0 & 91.6 & 8.4 \\
\hline 15. & Fearless Voting & 50.0 & 50.0 & 60.0 & 40.0 & 25.0 & 75.0 & 91.6 & 8.4 \\
\hline
\end{tabular}

The IDPs were asked whether these attributes of civil and political rights were affected negatively or positively before/after the displacement. The similar question of negative/positive status of civil and political rights on IDPs before and after their displacement was asked to the respondents (table 3, column 4). Mixed responses were received through both data collection tools. The interviewees were asked an open-ended question "what were the causes of changes on the status of civil and political rights before and after displacement?". The discussion hereunder includes those empirical causes received from the respondents to explain the changes on the condition of the civil and political rights.

The IDPs stated that there was no change on the personal and family security aspect in the previous election and the elections held after their displacement i.e. local, provincial and federal elections. On the same issue, interviewees found improvements and the cause was change on the circumstances that the constitutional assembly election was held aftermath of the armed conflict. The interviewees claimed that the rights to freedom of movement, association, expression, joining political parties, participating in the political activities and security of movements of the voters during election were better later. The rational put forward was the improved situation from conflict to peace through political peace process. IDPs contrarily stated that freedom of participating in political activities and political campaign decreased by respectively by 14 and 46 percentages. Opposingly, around 80 percent interviewees claimed the political participation is improved due to the resolution of armed conflict. Here, IDPs' claim seems logical as most of the displaced people were out of their villages concentrating in the less vulnerable geographic locations or some are even relocated and settled in the safer places by the government order. Let us take the case of relocated Boch Village. It is obvious that twenty families of Boch-4 (now Bhimeshwor Municipality- 3) in Dolakha District, living in the Setidevi Community Forest in Boch-3 (now Bhimeshwor Municipality-8), are unable to become the usual element of the village where their documents belong to. Feasibility of their involvement in the political activities cannot remain conclusive. It is not compatible with the spirit of the Civil Rights Act (1955) that all citizens have right to freedom of expression, peaceful assembly and associations, and not even with the provisions of ICCPR.

Displacement displaces rights of the displaced persons (Franke, 2008). We could find negative impact on the rights of the disaster induced IDPs as shown in the table 1 and 2. Protection is the central anxiety in the post-disaster situation (Rubin, 2009). Protection of the individuals, community, children, women and elderly people are the main issues. As the signatory to the ICCPR, the burden of protection lies on the states and it should be an observable impact on the state party's actual behavior (Keith, 1999). Interviewees found that the condition of individual, family and community security has been getting better due to the increasing political stability. Financial problem and lack of basic needs have caused implications to women. Women are obliged to be more dynamic in social and economical activities to maintain their home. Few of those women became empowered and more vulnerable to domestic violence, exploitation and abuse. Some 16 percent IDPs agreed that there was violence and exploitation before 


\section{8 | Journal of APF Command and Staff College}

displacement but 30 percentages of them agree on after displacement. On the contrary, 62.5 percent interviewees agreed that there was such violence against women before but the situation is getting better after displacement. Not the displacement but advancement on the information communication technology and access of women to the authorities through women right activists has contributed to ameliorating women condition.

Around 90 percent IDPs lost their houses due to the earthquake. In such situations, we find menace against right to adequate housing (García Amado, 2016). It took time to reach the relief items including shelter to the affected areas due to the damages on the infrastructure. Some interviewees stated that the geographic and political biasness on the distribution of the relief items was detrimental to the right to basic needs including shelter. There is need of field-based agencies to support the IDPs for addressing the daily problems (Guego, 2017). Governmental and non-governmental initiatives to ensure easy access of the affect population will minimize such tribulations. Insufficient budget to support the displaced persons has been common issue elsewhere (Guego, 2017). Government's proper response to the citizens' voice through answerable mechanism can decrease grievances. About 50 percent respondents of the questionnaire found that government authority's response to the problems is unsatisfactory. Opposingly, 75 percent of the interviewees said that response was negative before but 83.3 percent claimed the government response is good now. The reason for improved government response, as claimed by the interviewees, is the establishment of the local government through the election. To guarantee the civil and political rights, a good political system is able to respond to the preference of its people (Hobolt \& Klemmemsen, 2005). Here, the main role to support the people of the affected country comes to the court of international community. Capacity-building initiatives of international agencies in favour of IDPs will strengthen the government's response (Guego, 2017).

We see the agenda of human dignity of huge priority in the social/political movements but in practice is thinning (McCrudden, 2008). IDPs who found human dignity and respect in decreasing trend after their displacement are more by 20 percent than before displacement and equal interviewees agree on the lessening values due to the effect of modernity. Similarly, preventing social detachment among older individuals is the emerging concern of today's community (Sander et al., 2015). Fifty percent of the respondents of the questionnaire found the respect and security of the children and senior citizens was good before but only 30 percent agree for the respect after displacement. At the same time, 37.5 percent interviewees gave negative response for the status of protection of the children and elderly people after the displacement which was 16.7 percent for before displacement. Protection of the children and elderly people has been vulnerable due to the displacement.

IASC guidelines (2011) also protects the rights of the IDPs to documentation, freedom of movement and participate in public affairs. The rights to peaceful association and assembly of the people are protected by United Nations ("UDHR," 1948). IDPs' rights to vote, participate in governmental and public affairs are protected by "Guiding principles on internal displacement," (1998) as well. Successful promulgation of the Constitution of Nepal 2015 through the elected Constituent Assembly and affirmative political development has contributed for the elevation of the civil and political right situation. Judiciously employed election has constructive repercussion on postconflict peace and reconstruction (Flores \& Nooruddin, 2012). Fifty percent of both respondents stated that the freedom of association was positive, and 73.3 percent of the IDPs and 83.3 percent of the interviewees claimed that condition of associative right is better. Positive associative freedom is required to fulfill the social needs of the people (Brownlee, 2015). Both respondents said that freedom of joining political party of own interest has been good. This freedom is coincidently aligned with after the displacement however the open-ended responses of the interviewees show that improvement on most of the rights incorporated in the table 3 is due to the sociopolitical development of the country from conflict to constitution to Nepal election 2017. About 90 percent of both respondents said that expressive right is better later. The right to freedom of expression is quite good after the constitution that positively affected the IDPs' response as well. Freedom of expression is vital for the development of an individual and for expansion of democratic civilization (Howie, 2018).

Parties spend huge resources for campaigns to win the elections (Gowda \& Sridharan, 2012). Misusing the resources to attract the voters hinders the fair periodic election of any democratic culture. Nearly 50 percent of the IDPs agree that there were happenings of luring voters during election even before their displacement but 70 percent of them agreed on its augment after displacement. Similarly, 62.5 percent of the interviewees agreed that IDPs are attracted for voting through unethical means. We can connect this 
statistics to the data of table 2, which shows IDPs were in terrible scarcity of essentials after displacement. Fulfilling basic requirements at the movement was choiceless option for the IDPs and this condition was exploited during election campaign. The pitiable circumstances forced the IDPs not to rebuff the funds and supplies offered by the election campaigners. Unethical enticing voters hinder the fundamental of any democracies that is free and fair periodic election. IDPs might have wrongly casted their voting rights influenced by those offerings during election campaign. Providing assistance to ensure basic needs and assured security system become supportive to minimize immoral election campaigns. Around 50 percent of the respondent IDPs stated that security of the movement was almost similar during previous and this elections. On the contrary, only 25 percent interviewees claimed there was good security of movement in previous election and 91.6 percent surprisingly claimed the local election was good. On the response to the question whether the voting was fearless or not, about 50 percent of the IDPs stated both elections - constituent assembly and local - were good. At the same time, interviewees conflictingly stated that previous election was fearful (75\%) and later one went fearless (91.6\%). The reason for this drastic improvement as per the interviewees was recovered political setting in the country after the promulgation of the constitution.

\section{Conclusion}

The paper concludes that displacement caused detrimental effect on some of the civil and political rights of the IDPs. Lessening human dignity and protection of children and elderly people has become common concern in the situations like displacement. The changes on the circumstances due to the displacement cause women to be more involved in socio-economic activities which resulted in ongoing violence and exploitation against women. It was found that government has been slightly responsive to address people's problems. Authority's responsiveness will obviously minimize the general grievances. Associative and expressive freedom is in good status and needs small progress. The study found freedom of participation in political activities and political campaigning need to be improved as ensured political participation is the backbone of democracy. Immoral activities of attracting voters can raise question on the free and fair election. Offering resources during constituent assembly and local election campaigns might have lured IDPs. Improvement on the position of the IDPs to fulfill their essentials can minimize unnecessary influences for voting. Further study to probe the ways to reduce bad effect on free and fair election in the situations of displacement can be an interesting topic for further study. The scholars can find the issue "what emotional and mental trauma the IDPs went through and how the health facilities to overcome the issues can be ensured" can also be an area of further study.

\section{References}

Adekola, P. O., Allen, A. A., \& Tinuola, F. R. (2017). Socio-economic and health implications of urban renewal on internally displaced persons in Ogun State, southwestern Nigeria. Journal of Internal Displacement, 7(1), 16-30.

African Union convention for the protection and assistance of internally displaced persons in Africa. (2009). African Union. Retrieved from https://au.int/sites/default/files/treaties/7796-treaty-0039__kampala_convention_african_union_convention_for_the_protection_and_assistance_of_internally_d isplaced_persons_in_africa_e.pdf

Ambe-Uva, T. N. (2012). The right to education for internally displaced persons in Nigeria through open and distance learning. Huria: Journal of the Open University of Tanzania, 13(2), 359-372.

Banks, C. P., \& Carbonell, J. R. (2013). International human education rights commitments in US courts. The International Journal of Human Rights, 17(3), 391-410. https://doi.org/10.1080/13642987.2012.742069

Brownlee, K. (2015). Freedom of association: It's not what you think. Oxford Journal of Legal Studies, 35(2), 267-282. https://doi.org/10.1093/ojls/gqu018

Casla, K. (2016). The rights we live in: Protecting the right to housing in Spain through fair trial, private and family life and non-retrogressive measures. The International Journal of Human Rights, 20(3), 285297. https://doi.org/10.1080/13642987.2015.1073716

Civil and political rights. (2001). [International Nongovernmental Organization]. Retrieved January 1, 2019, from https://www.frontlinedefenders.org/en/right/civil-political-rights

Civil Rights Act, Pub. L. No. 12, 6 (1955). Retrieved from http://www.lawcommission.gov.np/en/documents/2015/08/civil-rights-act-2012-1955.pdf 
40 | Journal of APF Command and Staff College

Cohen, R. (2004). Some reflections on national and international responsibility in situations of internal displacement. In O. Mishra (Ed.), Forced migration in the South Asian region: Displacement, human rights, and conflict resolution (1st ed, pp. 343-356). Kolkata : Delhi: Centre for Refugee Studies, Jadavpur University in collaboration with Brookings Institution-SAIS Project on Internal Displacement, Washington DC; Manak Publications.

Constitution of Nepal. (2015). Government of Nepal. Retrieved from http://www.lawcommission.gov.np/en/documents/2016/01/constitution-of-nepal-2.pdf

District Development Committee, Dolakha. (2015). Dolakha development bulletin (Special Edition No. 12) (p. 210). Dolakha. Retrieved from http://ddcdolakha.gov.np/wp-content/uploads/2016/01/Full-Book.pdf

Elisabeth Koch, I. (2006). Economic, social and cultural rights as components in civil and political rights: A hermeneutic perspective. The International Journal of Human Rights, 10(4), 405-430. https://doi.org/10.1080/13642980601019730

Eweka, O., \& Olusegun, T. O. (2016). Management of internally displaced persons in Africa: Comparing Nigeria and Cameroon. African Research Review, 10(1), 193-210. https://doi.org/10.4314/afrrev.v10i1.15

Fagen, P. W. (2004). The long-term challenges of reconstruction and reintegration: Case studies of Haiti and Bosnia-Herzegovina. In E. Newman \& J. van Selm (Eds.), Refugees and forced displacement: international security, human vulnerability, and the state (pp. 221-249). Tokyo ; New York: United Nations University Press.

Flores, T. E., \& Nooruddin, I. (2012). The effect of elections on postconflict peace and reconstruction. The Journal of Politics, 74(2), 558-570. https://doi.org/10.1017/S0022381611001733

Franke, M. F. N. (2008). The displacement of the rights of displaced persons: An irreconciliation of human rights between place and movement. Journal of Human Rights, 7(3), 262-281. https://doi.org/10.1080/14754830802202100

García Amado, P. (2016). Connecting tenure security with durable solutions to internal displacement: From restitution of property rights to the right to adequate housing. International Migration, 54(4), 74-86. https://doi.org/10.1111/imig.12244

Gowda, M. V. R., \& Sridharan, E. (2012). Reforming India's party financing and election expenditure laws. Election Law Journal: Rules, Politics, and Policy, 11(2), 226-240. https://doi.org/10.1089/elj.2011.0131

Guego, E. (2017). IDPs in Colombia: The necessary step towards effective protection. Deusto Journal of Human Rights, (3), 115. https://doi.org/10.18543/aahdh-3-2006pp115-166

Guiding principles on internal displacement. (1998). United Nations. Retrieved from http://www.brookings.edu/ /media/Projects/idp/GPEnglish.pdf

Hobolt, S. B., \& Klemmemsen, R. (2005). Responsive government? Public opinion and government policy preferences in Britain and Denmark. Political Studies, 53(2), 379-402. https://doi.org/10.1111/j.14679248.2005.00534.x

Howie, E. (2018). Protecting the human right to freedom of expression in international law. International Journal of Speech-Language Pathology, 20(1), 12-15. https://doi.org/10.1080/17549507.2018.1392612

IASC operational guidelines on the protection of persons in situations of natural disasters. (2011). Washington D.C., USA: The Brookings - Bern Project on Internal Displacement. Retrieved from http://www.ohchr.org/Documents/Issues/IDPersons/OperationalGuidelines_IDP.pdf

Internal Displacement Monitoring Centre. (2018). Internal displacement database. London, UK. Retrieved from http://www.internal-displacement.org/database/displacement-data

International Covenant on Civil and Political Rights. (1966). United Nations. Retrieved from https://trities.un.org/doc/Treaties/1976/03/19760323\%2006-17\%20AM/Ch_IV_04.pdf

International Organization for Migration. (2015). IOM launches response in quake-shattered Nepal. Kathmandu, Nepal. Retrieved from http://nepal.iom.int/jupgrade/index.php/en/pressroom?id=140:iom-nepal-overview-5

Keith, L. C. (1999). The United Nations International Covenant on Civil and Political Rights: Does it make a difference in human rights behavior? Journal of Peace Research, 36(1), 95-118.

https://doi.org/10.1177/0022343399036001006 
Lischer, S. K. (2008). Security and displacement in Iraq: Responding to the forced migration crisis. International Security, 33(2), 95-119.

Man dies in Dolakha police firing. (2017, May 14). The Kathmandu Post. Retrieved from http://kathmandupost.ekantipur.com/news/2017-05-14/man-dies-in-dolakha-police-firing.html

Map of beneficiaries in Dolakha. (2018). [Government]. Retrieved December 11, 2018, from http://www.nra.gov.np/np/map/details/iDgt__cW1q2GBEYPDe6ffMrr7GnHUEer2HzbNBoGQLs

McCrudden, C. (2008). Human dignity and judicial interpretation of human rights. European Journal of International Law, 19(4), 655-724. https://doi.org/10.1093/ejil/chn043

Mertus, J. (2004). Sovereignty, gender, and displacement. In E. Newman \& J. van Selm (Eds.), Refugees and forced displacement: international security, human vulnerability, and the state (pp. 250-273). Tokyo; New York: United Nations University Press.

National policies on internally displaced persons. (2007). Ministry of Peace and Reconstruction, Government of Nepal.

National policy on internally displaced persons (IDPs) in Nigeria. (2012, August). Federal Republic of Nigeria. Retrieved from https://www.refworld.org/pdfid/5a7ae2324.pdf

Nepal third in internal displacement by natural disasters. (2016, May 11). The Himalayan Times. Retrieved from https://thehimalayantimes.com/nepal/nepal-ranks-third-in-internal-displacement-caused-bynatural-disasters-grid-2016/

Orach, C. G., Musoba, N., Byamukama, N., Mutambi, R., Aporomon, J. F., Luyombo, A., \& Rostedt, A. (2009). Perceptions about human rights, sexual and reproductive health services by internally displaced persons in northern Uganda. African Health Sciences, 9(2), S72-S80.

Rekhviashvili, L. (2015). The politics of helping: Internally displaced persons after the 2008 Russia-Georgia war. Journal of Internal Displacement, 5(2), 2-18.

Rubin, C. B. (2009). Long term recovery from disasters: The neglected component of emergency management. Journal of Homeland Security and Emergency Management, 6(1). https://doi.org/10.2202/1547-7355.1616

Salgado-Gálvez, M. A. (2018). Estimating the lost economic production caused by internal displacement because of disasters. International Journal of Disaster Risk Science, 9(4), 496-506. https://doi.org/10.1007/s13753-018-0190-9

Sander, M., Oxlund, B., Jespersen, A., Krasnik, A., Mortensen, E. L., Westendorp, R. G. J., \& Rasmussen, L. J. (2015). The challenges of human population ageing. Age and Ageing, 44(2), 185-187. https://doi.org/10.1093/ageing/afu189

Toebes, B. (2015). Human rights and public health: Towards a balanced relationship. The International Journal of Human Rights, 19(4), 488-504. https://doi.org/10.1080/13642987.2015.1044814

Universal Declaration of Human Rights. (1948). UNOHCHR. Retrieved from http://www.ohchr.org/EN/UDHR/Documents/UDHR_Translations/eng.pdf

Yigen, K. (2000). Enforcing social justice: Economic and social rights in South Africa. The International Journal of Human Rights, 4(2), 13-29. https://doi.org/10.1080/13642980008406873 